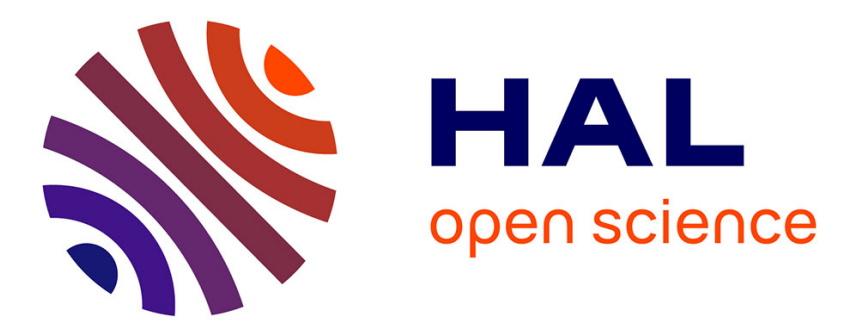

\title{
Empirical Analysis of Freight Transport Prices Using the French Shipper Survey ECHO
}

\author{
François Combes, Julien Harache, Martin Koning, Eric Morau
}

\section{To cite this version:}

François Combes, Julien Harache, Martin Koning, Eric Morau. Empirical Analysis of Freight Transport Prices Using the French Shipper Survey ECHO. 2nd Interdisciplinary Conference on Production Logistics and Traffic, Jul 2015, DORTMUND, Germany. 15p. hal-01920396

\section{HAL Id: hal-01920396 https://hal.science/hal-01920396}

Submitted on 13 Nov 2018

HAL is a multi-disciplinary open access archive for the deposit and dissemination of scientific research documents, whether they are published or not. The documents may come from teaching and research institutions in France or abroad, or from public or private research centers.
L'archive ouverte pluridisciplinaire HAL, est destinée au dépôt et à la diffusion de documents scientifiques de niveau recherche, publiés ou non, émanant des établissements d'enseignement et de recherche français ou étrangers, des laboratoires publics ou privés. 


\title{
Empirical analysis of freight transport prices using the French shipper survey ECHO
}

\section{$2^{\text {nd }}$ Interdisciplinary Conference on Production, Logistics and Traffic}

\author{
François Combes
}

Technical Division for Transportation Infrastructure and Materials, Cerema, Cité des Mobilités, B.P. 214, 77487 Provins Cedex - France

French Institute of Science and Technology for Transport, Development and Networks - East Paris University, Cité Descartes, 14-20 bvd. Newton, 77447 Marne-la-Vallée Cedex 2 -

France

\section{Julien Harache}

Territorial Division for the Western Regions, Cerema, Maison de l'administration nouvelle, 9 rue René Viviani, B.P. 46223, 44262 Nantes Cedex 2 - France

\section{Martin Koning}

French Institute of Science and Technology for Transport, Development and Networks - East Paris University, Cité Descartes, 14-20 bvd. Newton, 77447 Marne-la-Vallée Cedex 2 -

France

\section{Eric Morau}

Territorial Division for the Western Regions, Cerema, Maison de l'administration nouvelle, 9 rue René Viviani, B.P. 46223, 44262 Nantes Cedex 2 - France

\begin{abstract}
This article presents an empirical analysis of the prices' structure in the road freight industry. For that purpose, we use the French ECHO survey that provides detailed information on the characteristics of shippers and transport operators. First, we show that road freight prices are not a simple linear function of shipments' attributes. Second, the main determinants of these prices are related to "technical" attributes of the transport services (load weight, travel duration, dis-
\end{abstract}


tance) but also to the characteristics of the shipped goods (density value, commodities constrains). Lastly, the influence of "non-traditional" factors (intensity of the shipper-operator relationship, size of the shipper, intra-group shipments) is highlighted.

\section{Introduction}

Freight transport is a complex system: it plays a pivotal role in supply chains of firms, which are very heterogeneous in their geography, characteristics, requirements, etc. It also causes heavy environmental and congestion impacts, particularly in cities. As a consequence, freight is a center of attention for public deciders willing to promote sustainable transportations.

In the decisions of shippers, prices paid to carriers for transport operations play a central role. For example, changes in fuel prices, vehicle taxes or tolls will have an influence on shippers through the prices they have to pay. The analysis of prices can also reveal the willingness of shippers to pay for other characteristics of freight transport, such as speed and logistics operations. Given the fact that road freight transport is essentially a multiproduct industry, multivariate econometric analyses seem to be an adequate tool to assess the structure of its prices and to disentangle the relative importance of the multiple services embedded within transport operations. Having a good understanding of the road freight prices' structure is of prime interest for policy makers since their interventions may impact differently the various components of transport operations.

This paper explores empirically road freight prices thanks to the French survey ECHO. ECHO is a commodity flow survey with a very large range of information about shippers, shipments, and transport operations. Prices are studied with the objective to identify the respective roles of the cost structure of carriers, the preference of shippers, market structure and transaction costs in the formation of road freight transport prices.

The paper proceeds as follows. Section 2 reviews the literature on the structure of road freight costs and prices. Section 3 presents the ECHO database and analyses the variables used for the empirical tests. Section 4 presents the econometric methodology and outcomes. Section 5 concludes the paper.

\section{Costs and prices in freight transport}

Road freight transport is a complex transport system, and also a complex market, or more precisely a large set of partially substitutable markets. Road freight operations are characterized by a number of attributes: origin, destination, departure and arrival time, shipment size, reliability, flexibility, conditioning, number of trans- 
shipments, etc. Some are important to the shippers, others are important to the carriers. Both have a direct influence on costs and prices.

\subsection{From the carriers' perspective}

An important driver of the price of a given transport operation is the marginal production cost: in theory, a given carrier will produce operations so that his marginal benefit is, at least, equal to its marginal production $\operatorname{cost}^{1}$. Marginal costs mirror the structure of the production function, which depends itself on the type of transport operation. As a matter of fact, the following properties of freight transport marginal costs can be intuited, all other things equal. Some logically increase marginal production costs; others are more ambiguous with that respect:

- Commodity type and conditioning: transport costs depend on the nature of the commodity. For example, transporting fragile commodities, hazardous materials, or refrigerated products requires specific assets and expenses;

- Mileage driven: longer distances are more expensive due to the additional needs of fuel, vehicle immobilization and wear and tear, tolls, drivers' wages, and other consumables;

- Transport speed: faster transport is expected to be more expensive, due to more recent vehicles, the additional fuel expenses, the fares paid to use faster infrastructures (highways), as well as the fewer opportunities to transport distinct shipments together. However, faster transport also means less vehicle immobilization costs and driver costs (Strandenes, 2013);

- Shipment size: larger shipments are more expensive to carry because they use more of the vehicles' capacities, and they sometimes need bigger vehicles. However, bigger vehicles are less expensive on a per ton basis (Kay and Warsing 1999, Strandenes, 2013);

- Route structure: transport operations with transshipments are more costly because they involve detours and transshipment operations, although they can be less costly on a per shipment basis, because they offer an opportunity for consolidation that direct transport does not (Combes and Tavasszy, 2013);

- Spatial coverage: urban transport is more expensive than interurban transport due to congestion, but consolidation - through vehicle rounds for example - is easier: transporting smaller shipments inside cities is easier than outside cities, the contrary is expected for larger shipments;

- Reliability: the probability that the shipment is delivered at the time initially announced can be increased by increasing buffer times, applying more demanding procedures, etc., at an increased cost for carriers;

\footnotetext{
${ }^{1}$ In practice, it appears that some carriers, particularly one-man businesses, are structurally unprofitable.
} 
- Flexibility: the possibility to send shipments with short (or no) notice and/or toward a wide range of destinations is expected to be more expensive because it limits the ability of carriers to share their resources and to decrease costs (Strandenes, 2013);

- Safety: the probability that the shipment is delivered at all, and intact, is also expected to be more expensive, due to the additional constraints and more expensive resources it involved;

- Additional services: if logistic services (picking, handling, packaging, etc.) are realized together with the transport operation, they incur an additional cost.

Furthermore, the freight transport industry is essentially a multi-product industry. For example, freight transport from A to B and from B to A are essentially joint products, made by vehicles commuting between the two locations. Thus, it is impossible to isolate the marginal cost of transport in one direction from that of the other direction, and the prices will depend as much on the demand schedules as on the costs (Felton, 1981; Demirel, van Ommeren and Rietveld, 2010). Joint production also plays a complex role in the relationship between shipment size and freight rates (Combes, 2013).

\subsection{From the shippers' perspective}

From the perspective of shippers, freight transport is part of a logistic chain. The logistic chain's objective is to provide goods or services to customers at the right places and times, but also to a limited cost. The preferences of shippers regarding freight transport derive from their own logistic requirements. It is now customary, in the freight modeling literature, to model the preferences of shippers by a total logistic cost function (see e.g. Vinod and Baumol, 1970, or Ben Akiva and de Jong, 2013) which takes into account transport prices, travel time, travel time reliability, but also inventory and warehousing costs. More generally, shippers are willing to pay to improve transport speed and reliability (de Jong, 2014), or to send smaller, more frequent shipments to their receivers, because it limits the capital opportunity cost associated to owning the commodities, and it offers a better flexibility and reliability of the supply chain (Baumol and Vinod, 1970). As a consequence, we easily understand that the various factors detailed previously for the freight producer also matter for the shippers.

Somehow symmetrically to the decision of carriers, shippers will not agree to bear one road freight price that exceeds their marginal willingness to pay for a given transport operation. Since that operation is made of various characteristics (speed, safety, logistics operations, etc), the prices paid to carriers should be consistent with the marginal benefits linked to each dimension of the transport service, from the shipper's perspective. As highlighted by the "hedonic price" methodology (Rosen, 1974, Haab and McConnel, 2003) in the case of multidimensional products (e.g. housing notably), equilibrium prices on the road 
freight market should consequently equalize, for each characteristic, the marginal production cost of carriers to the marginal willingness to pay of shippers, making so-called "shadow prices" for various attributes.

\subsection{Other determinants}

Importantly, we believe that road freight prices do not only depend on costs and benefits: two other dimensions also play a crucial role: transaction costs, and market structure.

Transaction costs refer to the efforts or resources associated with finding the most relevant contracting party, deciding the terms of the contract and monitoring the transaction. Given the attributes involved with a road freight transport operation, these costs are probably substantial; although the existence of online marketplaces would let think otherwise. Transaction costs may depend on the technology with which the shipper, receiver and carrier communicate together. They may also depend on the economic size of the agents; a bigger shipper (i.e. sending more shipments per year) may benefit from reduced transaction costs due to "relational" agreements. Thus the transaction frequency is often thought to decrease the need for contractual "completeness" (thus reducing "ink costs").

Market structure regards the existence of "market powers", either on the supply or on the demand side. Road freight transport is often considered a very competitive market. Although there has been some academic debates on this topic at the time it was deregulated, the low requirements in terms of fixed capital insures "free-entry" onto the market. Empirical analyses of the structure of road freight transport costs mostly concluded to constant returns to scale (Xu et al., 1994), consistent with strong competition. As a consequence, prices should not divert significantly from marginal costs since no "mark-up" should be applied. Nevertheless, some sub-markets of road freight transport are clearly, at best, monopolistic; this is the case of express transport (flat freight rates commonly found in this market can theoretically be considered as consistent with third type price discrimination, exercised by a monopoly - Tirole, 1988), for example, or for some "niche" markets which are characterized both by their relatively small size and by the specific transport techniques they involve (oversized transportation, cash transport). Also, some empirical studies concluded that road freight transport exhibited ad valorem pricing, which is not consistent with perfect competition (Szpiro, Hanappe and Gouvernal, 1996; Reme-Harnay, 2012).

Road freight transport should be considered as a large number of closely related markets, characterized by multiple attributes, with a non-trivial market structure. Prices mirror both the cost structure of carriers, the preferences of shippers, and may be strongly influenced by their relative market powers. In this context, multivariate econometric analyses are expected to yield particularly instructive conclusions. They should allow computing the willingness of shippers to pay for variations of the attributes of road freight transport operation. Our empirical work 
relies on a rich dataset (ECHO) whose latest version has never been used for this purpose $^{2}$. This dataset has two specific properties: first, the transport operations are described in detail, including the number of transshipments. Second, the database also provides information on the shipper, the receiver, and their relationship. As explained in the next section, it makes it possible to test the influence of many variables which are generally absent from freight transport databases.

\section{Data}

\subsection{The ECHO Survey}

ECHO is a French shipper survey, carried out in 2004-2005. The dataset provides information on 10,462 shipments sent by 3,000 French shippers, obtained by faceto-face and phone interviews, based on closed questionnaires. It is similar to a commodity flow survey or CFS; its main particularity is that it provides very detailed information on the shipper-receiver relationship, and on the way the shipments were transported (Guilbault, 2008; Guilbault and Gouvernal, 2010).

In the ECHO survey, shippers are described by their location, activity type, number of employees, turnover, but also by the total number of tons of commodities and the total number of shipments they send or receive per year, the number of customers which account for $80 \%$ of their demand, etc. Similar information is available about the receivers. The shipments are described by their commodity type, weight, value, conditioning, etc; the shipper-receiver relationship is also described (yearly commodity flow rate, means of communication, etc.), as well as the transport operation (mode, sequence of elementary transport operations, transport price and duration, etc.)

In the ECHO database, shipments are carried by road (own account and for hire), railway, combined transport, inland waterway, air and sea. In order to work on a sufficiently homogenous sample, we selected the shipments carried by road, by commercial haulage companies, with their destination in the EU 15 . This represents 4,561 shipments over the 10,462 shipments of the full dataset (44\%).

\subsection{Variables of interest}

This section describes the variables used in the econometric analysis. The dependent variable is the price paid by the shipper or the receiver for the transport of

\footnotetext{
2 Szpiro, Hanappe and Gouvernal (1996) and Massiani (2008) have crossed previous waves of the ECHO survey with the hedonic price methodology in order to assess the values put on various freight characteristics and freight time savings respectively.
} 
the shipment. The ECHO dataset distinguished three cases: either the price was fully paid by the shipper, or it was fully paid by the receiver, or neither. Besides the dataset does not say what the prices cover exactly (FOB, CIF, etc.). This is an inherent source of inaccuracy of the data. In the following, we kept shipments either in the first or the second case, not the third (because we were not certain that the totality of the price was accounted for in the latter case).

The empirical analysis presented in the following section involves a number of explanatory variables. The ECHO dataset contains a lot of variables; those for which the definition was unclear or with too-many missing values were not kept. Based on our discussion in Section 2, the variables kept for the econometric analysis may be categorized into four groups:

- Supply variables: those variables are expected to have a direct influence on transport costs, because they constitute constraints for carriers. This influence is expected to have an impact on prices. For example, the number of transshipments has a direct influence on costs.

- Demand variables: they characterize the shippers in ways which concretely influence the transport operation (e.g. the shipper-receiver distance, the commodity type), or have preferences regarding (e.g. travel time duration); they are willing to pay for an improvement in these variables;

- Transaction variables: those variables are related to the ease (or lack thereof) for a shipper to contract with a carrier or freight forwarder (e.g. bigger shippers would experience lower transaction costs per shipment); they should influence prices accordingly.

- Market structure variables: those variables are related to the market power of shippers, or carriers. For example, a bigger shipper may benefit from more competitive prices due to its size and ability to organize a fiercer competition; shippers in dense urban areas may not experience the same level of competition than shippers located in other places.

Table 1 lists the variables and table 3 in Appendix provides descriptive statistics of these variables. Table 1 indicates whether they are related to the supply or demand side, if they may be related to transaction costs, or to market structure.

Table 1: Variable list and categorization.

\begin{tabular}{|c|c|c|}
\hline Name & Definition & Categories $^{\mathrm{a}}$ \\
\hline Price & $\begin{array}{l}\text { Price (paid by the carrier or the receiver) of the transport oper- } \\
\text { ation }(€)\end{array}$ & \\
\hline Distance & Shortest road distance $(\mathrm{km})$ & $\mathrm{S}, \mathrm{D}$ \\
\hline Duration & $\begin{array}{l}\text { Time between the start of the first transport operation and the } \\
\text { end of the last transport operation }(\mathrm{h})\end{array}$ & S, D \\
\hline Nb_traj_i & Number of transport operations is equal to $i(1,2 \text { or } 3+)^{\mathrm{b}}$ & $\mathrm{S}, \mathrm{M}$ \\
\hline Weight & Shipment weight (kg) & $\mathrm{S}, \mathrm{D}$ \\
\hline Condi_i & $\begin{array}{l}\text { Conditioning of the commodity is of type } i \text { (bulk, palletized, } \\
\text { containers, all kinds) }\end{array}$ & $\mathrm{S}, \mathrm{D}$ \\
\hline
\end{tabular}




\begin{tabular}{|c|c|c|}
\hline Constraint_i & \multicolumn{2}{|l|}{$\begin{array}{l}\text { Commodity requires handling precautions of type } i \text { (hazardous } \mathrm{S}, \mathrm{D} \\
\text { material, fragile, controlled temperature) }\end{array}$} \\
\hline Val_dens & Value density of the shipment $(€ / \mathrm{kg})$ & $\mathrm{S}, \mathrm{D}, \mathrm{M}$ \\
\hline $\mathrm{NSTi}^{\mathrm{c}}$ & Commodity belongs to commodity type $i$ & S, D \\
\hline Production_prog ${ }^{\mathrm{d}}$ & The shipment's production was planned (make-to-stock). & $\mathrm{D}$ \\
\hline Total_shipper & $\begin{array}{l}\text { Total number of shipments sent by the shipper per year (ship- } \\
\text { ment/y) }\end{array}$ & $\mathrm{S}, \mathrm{T}, \mathrm{M}$ \\
\hline Shipper_workforce & Number of employees of the shipper & $\mathrm{T}, \mathrm{M}$ \\
\hline \multicolumn{3}{|c|}{$\begin{array}{l}\text { Shipper_receiver_flowTotal amount of commodities sent by the shipper to the receiv-S, T, M } \\
\text { er per year }(\mathrm{t} / \mathrm{y})\end{array}$} \\
\hline Shipper_pop & Population of the urban unit to which the shipper belongs & $\mathrm{S}, \mathrm{M}$ \\
\hline Same_firm ${ }^{\mathrm{d}}$ & The shipper and the receiver belong to the same firm & $\mathrm{T}$ \\
\hline Same_group ${ }^{\mathrm{d}}$ & The shipper and the receiver belong to the same group & $\mathrm{T}$ \\
\hline E_mail_contact ${ }^{\mathrm{d}}$ & Contact between the shipper and the carrier was by e-mail & $\mathrm{T}$ \\
\hline
\end{tabular}

${ }^{\mathrm{a}}$ The categories are S: Supply, D: Demand, T: Transaction costs, M: Market structure

${ }^{\mathrm{b}}$ More detail are available in the ECHO database, it was dropped either because the definitions were unclear or to keep the results legible.

c The NST are the categories of commodities in French freight transport databases before 2007. In the ECHO dataset, the following categories are met: NST 0 (agri-food sector), NST1 (food products), NST 3 (petroleum products), NST4 (ores for the metal industry), NST 5 (metals), NST 6 (minerals and building materials), NST 7-8 (fertilizers and chemical products - the two NSTs are merged in ECHO), NST 9 (manufactured products). NST 2 (solid fuels) is absent from ECHO.

${ }^{\mathrm{d}}$ Is equal to 1 if true, 0 else.

Unavoidably, this classification is most often ambiguous. Few variables belong to only one category. The number of transport operations is one of them: clearly relevant to carriers, because the technologies involved by direct and break-bulk transport are entirely different, it should be transparent for shippers. Besides, it may also have an influence in terms of market structure: the level of competition may not be the same between direct transport and break-bulk transport.

Most of the other shipment related variables are relevant for both shippers and carriers. Value density plays a specific role. In theory, it should not be important to carriers; in practice, it may be associated with specific constraints increasing significantly the transport costs, such as safety, flexibility, or reliability, which are either not or incorrectly measured in the ECHO database. It may also be associated with ad valorem pricing, theoretically not possible under perfect competition, thus providing information about the road freight transport market structure.

The variables describing the shippers should provide information related to the market structure, or to transactions costs: an influence of shipper size (measured in number of employees or in the amount of commodities sent per year, total or towards a given receiver) on prices would indicate a stronger market power, or decreased transaction costs. Transaction costs may also be analyzed through the relationship between the shipper and the receiver (do they belong to the same firm?) and through the communication technology between the shipper and the carrier 
(did they communicate by e-mail?); in both cases, a positive answer would be associated to lower transaction costs.

\section{Empirical study}

\subsection{Model specification}

Empirical studies looking at the price structure of multidimensional products generally allow the greatest flexibility in model specifications (Halvorsen and Pollakowski, 1981, Cassel and Mendelsohn, 1985). For that purpose, the Box-Cox transformation is often used (Haab and McConnel, 2003, Massiani, 2008):

$$
P^{(\theta)}=\alpha_{0}+\sum_{i=1} \alpha_{i} X_{i}^{(\delta)}+\varepsilon_{i}
$$

Where $P^{(\theta)}$ denotes the dependent variable (the price paid for the transport service) and $X_{i}^{(\delta)}$ a vector of explanatory variables (characteristics of the transport service). Parameters $\alpha_{i}$ have to be estimated in order to estimate the shadow prices of characteristics $X_{i}$. $\varepsilon_{i}$ represents the error term (unobserved determinants of the price) assumed iid. Importantly, $P^{(\theta)}$ and $X_{i}^{(\delta)}$ are Box-Cox transformations of the data. If we focus only on $P^{(\theta)}$, we get:

$$
P^{(\theta)}=\frac{\left(P^{\theta}-1\right)}{\theta} \text { if } \theta \neq 0 \text { and } P^{(\theta)}=\ln P \text { if } \theta=0
$$

Given the trade-off to be made between flexibility and tractability, we choose here to restrict the empirical analysis to only four specifications: lin-lin $(\theta$ and $\delta=1), \log -\log (\theta$ and $\delta=0), \operatorname{lin}-\log (1 ; 0)$ and $\log -\operatorname{lin}(0 ; 1)$. For each of these specifications, the model is estimated using the ordinary least squares methodology.

Four models are estimated in this paper:

- The complete log-log model: the logarithm transformation is applied to all continuous variables (dependent and explanatory). All the variables of Table 1 are introduced. Importantly, the log-log model allows us to interpret estimated parameters as elasticities. Note also that interaction terms between number of transport operations and the weight of the shipment as well as between value density and transport duration were introduced;

- The complete log-lin model: same as above, except for the continuous explanatory variables, which are not transformed;

- The consolidated log-log model: based on the complete log-log, but all nonsignificant explanatory variables were removed (a variable was removed when its $p$-value was higher than 0.1 )

- A simplified log-log model: the objective here was to keep the minimum number of variables, while keeping the most important features of the model: ship- 
ment size is kept, as well as the number of transshipments; other variables are the distance and commodity type.

A Box-Cox transformation was also tested on the dependent variable: the conclusion was that taking the logarithm of the price variable is an adequate choice.

\subsection{Results}

The models were estimated using the ordinary least square methodology. Table 2 presents the results. For each parameter, the table gives an estimation of its value, its $t$-stat and significance.

Table 2: model results.

\begin{tabular}{|c|c|c|c|c|}
\hline Name & $\begin{array}{l}\text { Complete } \\
\text { model } \\
(\log -\log )\end{array}$ & $\begin{array}{l}\text { Complete } \\
\text { model } \\
(\log -\operatorname{lin})\end{array}$ & $\begin{array}{l}\text { Consolidated } \\
\text { model } \\
(\log -\log )\end{array}$ & $\begin{array}{l}\text { Simplified } \\
\text { model } \\
(\log -\log )\end{array}$ \\
\hline Constant & $\begin{array}{r}1.102 \\
(3.89)^{* * *}\end{array}$ & $\begin{array}{r}4.527 \\
(38.51)^{* * *}\end{array}$ & $\begin{array}{r}0.8392 \\
(4.65)^{* *}\end{array}$ & 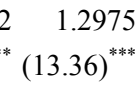 \\
\hline Distance & $\begin{array}{r}0.2014 \\
(8.38)^{* * *}\end{array}$ & $\begin{array}{c}1.342 * 10^{-4} \\
(11.66)^{* * *}\end{array}$ & $\begin{array}{r}0.1931 \\
(9.87)^{* * *}\end{array}$ & $\begin{array}{lr}1 & 0.2371 \\
& (18.69)^{* * *}\end{array}$ \\
\hline Nb_traj_2 & $\begin{array}{c}-0.5962 \\
(-3.39)^{* * *}\end{array}$ & $\begin{array}{r}-1.058 \\
(-11.29)^{* * *}\end{array}$ & $\begin{array}{c}-0.6192 \\
(-4.29)^{* *}\end{array}$ & $\begin{array}{ll}2 & -0.6695 \\
& (-6.17)^{* * *}\end{array}$ \\
\hline $\mathrm{Nb}$ _traj_3 & $\begin{array}{c}-0.9748 \\
(-6.25)^{* * *}\end{array}$ & $\begin{array}{r}-1.513 \\
(-17.30)^{* * *}\end{array}$ & $\begin{array}{c}-0.8275 \\
(-6.62)^{* *-}\end{array}$ & $\begin{array}{cc}5 & -0.7068 \\
& (-7.85)^{* * *}\end{array}$ \\
\hline Weight & $\begin{array}{r}0.4010 \\
(17.01 \mathrm{a})^{* * *}\end{array}$ & $\begin{array}{r}2.77 * 10^{-5} \\
(9.19)^{* * *}\end{array}$ & $\begin{array}{r}0.4364 \\
(27.61)^{* * *}\end{array}$ & $\begin{array}{lr}4 & 0.3793 \\
& (38.62)^{* * *}\end{array}$ \\
\hline $\mathrm{Nb}$ traj_ $2 *$ weight & $\begin{array}{r}0.0415 \\
(1.46)\end{array}$ & $\begin{array}{r}1.772 * 10^{-5} \\
(2.51)^{* *}\end{array}$ & $\begin{array}{l}0.0521 \\
(2.30)^{*}\end{array}$ & $\begin{array}{lr}1 & 0.0692 \\
& (4.18)^{* * *}\end{array}$ \\
\hline $\mathrm{Nb}$ traj_3 3 weight & $\begin{array}{r}0.1069 \\
(4.05)^{* * *}\end{array}$ & $\begin{array}{r}1.595 * 10^{-4} \\
(6.77)^{* * *}\end{array}$ & $\begin{array}{r}0.0834 \\
(4.03)^{* *}\end{array}$ & $\begin{array}{rr}4 & 0.068 \\
& (4.59)^{* * *}\end{array}$ \\
\hline Condi_freight_all_kind & $\begin{array}{l}-0.1790 \\
(-2.02)^{* *}\end{array}$ & $\begin{array}{c}-0.7658 \\
(-7.13)^{* * *}\end{array}$ & $\begin{array}{c}-0.1369 \\
(-2.67)^{* *}\end{array}$ & \\
\hline Condi_palletized & $\begin{array}{r}-0.0418 \\
(-0.53)\end{array}$ & $\begin{array}{c}0.2512 \\
(2.50)^{* *}\end{array}$ & & \\
\hline Constraint_hazmat & $\begin{array}{l}0.3526 \\
(2.19)^{* *}\end{array}$ & $\begin{array}{r}0.6262 \\
(3.01)^{* * *}\end{array}$ & $\begin{array}{c}0.3164 \\
(2.22)^{* *}\end{array}$ & \\
\hline Constraint_controlled_T & $\begin{array}{r}0.0760 \\
(0.58)\end{array}$ & $\begin{array}{r}0.095 \\
(0.426)\end{array}$ & & \\
\hline Constraint_fragile & $\begin{array}{l}0.1641 \\
(2.08)^{* *}\end{array}$ & $\begin{array}{r}0.1207 \\
(1.21)\end{array}$ & & \\
\hline
\end{tabular}




\begin{tabular}{|c|c|c|c|c|}
\hline Duration & $\begin{array}{r}0.0749 \\
(2.61)^{* * *}\end{array}$ & $\begin{array}{r}-9.969 * 10^{-6} \\
(-0.08)\end{array}$ & $\begin{array}{r}0.0792 \\
(3.54)^{* * *}\end{array}$ & \\
\hline Value_dens & $\begin{array}{r}0.2542 \\
(7.68)^{* * *}\end{array}$ & $\begin{array}{r}-3.468 * 10^{-4} \\
(-1.33)\end{array}$ & $\begin{array}{r}0.2790 \\
(10.88)^{* * *}\end{array}$ & \\
\hline Duration*val_dens & $\begin{array}{c}-0.0353 \\
(-3.74)^{* * *}\end{array}$ & $\begin{array}{r}-1.824 * 10^{-6} \\
(-0.36)\end{array}$ & $\begin{array}{r}-0.0320 \\
(-4.21)^{* * *}\end{array}$ & \\
\hline NST_0 & $\begin{array}{l}-0.3736 \\
(2.46)^{* *}\end{array}$ & $\begin{array}{l}-0.271 \\
(-1.46)\end{array}$ & $\begin{array}{l}-0.2125 \\
(-2.13)^{* *}\end{array}$ & $\begin{array}{c}-0.3464 \\
(-4.22)^{* * *}\end{array}$ \\
\hline NST_1 & $\begin{array}{r}-0.1346 \\
(-1.24)\end{array}$ & $\begin{array}{l}0.150 \\
(1.21)\end{array}$ & & $\begin{array}{c}-0.1593 \\
(-3.44)^{* * *}\end{array}$ \\
\hline NST_3 & $\begin{array}{r}0.9574 \\
(3.29)^{* * *}\end{array}$ & $\begin{array}{r}1.08 \\
(2.97)^{* * *}\end{array}$ & $\begin{array}{r}0.7588 \\
(2.92)^{* * *}\end{array}$ & \\
\hline NST_4 & $\begin{array}{l}0.6049 \\
(1.82)^{*}\end{array}$ & $\begin{array}{r}0.719 \\
(1.74)^{*}\end{array}$ & $\begin{array}{l}0.5057 \\
(2.01)^{* *}\end{array}$ & \\
\hline NST_5 & $\begin{array}{l}-0.2302 \\
(-1.77)^{*}\end{array}$ & $\begin{array}{r}0.034 \\
(0.208)\end{array}$ & & \\
\hline NST_6 & $\begin{array}{r}-0.1814 \\
(-1.18)\end{array}$ & $\begin{array}{l}-0.160 \\
(-0.85)\end{array}$ & & $\begin{array}{r}-0.3886 \\
(-3.95)^{* * *}\end{array}$ \\
\hline NST_78 & $\begin{array}{r}-0.1050 \\
(-1.28)\end{array}$ & $\begin{array}{l}-0.117 \\
(-1.14)\end{array}$ & & $\begin{array}{r}-0.1707 \\
(-3.39)^{* * *}\end{array}$ \\
\hline Production_prog_true & $\begin{array}{c}-0.1633 \\
(-3.07)^{* * *}\end{array}$ & $\begin{array}{r}0.0727 \\
(1.10)\end{array}$ & & \\
\hline Total_shipper & $\begin{array}{l}-0.0607 \\
(-3.67)^{* * *}\end{array}$ & $\begin{array}{c}-2.02 * 10^{-6} \\
(-3.79)^{* * *}\end{array}$ & $\begin{array}{r}-0.0504 \\
(-3.98)^{* * *}\end{array}$ & \\
\hline Shipper_workforce & $\begin{array}{l}0.0526 \\
(1.93)^{* *}\end{array}$ & $\begin{array}{c}2.56^{*} 10^{-4} \\
(2.01)^{* *}\end{array}$ & $\begin{array}{c}0.0424 \\
(2.05)^{* *}\end{array}$ & \\
\hline Shipper_receiver_flow & $\begin{array}{r}0.0202 \\
(0.77)\end{array}$ & $\begin{array}{r}-1.22 * 10^{-7} \\
(-0.019)\end{array}$ & & \\
\hline Shipper_pop & $\begin{array}{r}0.0089 \\
(0.76)\end{array}$ & $\begin{array}{r}4.62 * 10^{-9} \\
(0.33)\end{array}$ & & \\
\hline Same_firm & $\begin{array}{r}0.3253 \\
(2.75)^{* * *}\end{array}$ & $\begin{array}{c}0.3887 \\
(2.58)^{* *}\end{array}$ & $\begin{array}{r}0.2834 \\
(3.15)^{* * *}\end{array}$ & \\
\hline Same_group & $\begin{array}{l}0.2143 \\
(1.95)^{*}\end{array}$ & $\begin{array}{c}0.3207 \\
(2.32)^{* *}\end{array}$ & $\begin{array}{r}0.2120 \\
(2.39)^{* *}\end{array}$ & \\
\hline E_mail_contact & $\begin{array}{r}0.1050 \\
(1.64)\end{array}$ & $\begin{array}{l}0.1423 \\
(1.77)^{*}\end{array}$ & & \\
\hline Number of observations & 1142 & 1142 & 1910 & 4351 \\
\hline Model degrees of freedom & 29 & 29 & 19 & 14 \\
\hline$R^{2}$ & 0.7494 & 0.5963 & 0.7307 & 0.6515 \\
\hline Adjusted $R^{2}$ & 0.7430 & 0.5860 & 0.7281 & 0.6504 \\
\hline
\end{tabular}

Significance levels: ${ }^{* * *}$ means p-value $<0.01 ;{ }^{* *}$ means p-value $<0.05,{ }^{*}$ means p-value $<0.1$. 
The log-log specification performs best, with a $\mathrm{R}^{2}$ close to 0.75 . It performs significantly better than the log-lin model, which is not surprising given the very large and asymmetric dispersion of many of the explanatory variables.

The supply variables, in the sense of Section 3, have a strong influence on prices. Prices depend on shipment size, shipper-receiver distance, commodity type and conditioning. The coefficients are significant, and stable, whatever the model tested. The log-log models also show the strong non-linearity of freight prices: the elasticity to distance is only 0.2 , the elasticity to shipment weight is 0.4 . This non linearity was already identified in the literature; with the ECHO dataset, it is confirmed in the European context for a large and heterogeneous population of shippers and shipments.

Prices also depend strongly on the number of transshipments: Road freight operations with transshipments are cheap for small shipments, while direct transport is more competitive for large shipments. The road freight transport system is in fact a combination of interrelated systems, each adapted to a specific demand, deriving from distinct supply chains.

In regards with demand variables, the results are less clear, and more difficult to interpret. Consider the case of transport duration: as discussed in Section 2, shippers would be ready to pay for lower durations, particularly so for commodities with a higher density value. The coefficient of interaction between transport duration and value density has the right sign, but not the coefficient of transport duration alone. In practice, an increase in transport duration decreases transport price only if the value density is larger than $8 € / \mathrm{kg}$. This is only the case of half the shipments in the dataset used in this study (Massiani (2008) reached similar conclusions). Several causes may explain that result. Travel time may differ between two origin-destinations which are at the same road distance from one another. In that case, the longer travel time is more expensive for carriers, thus the price increase. Finally, transport duration does not seem to be reliably measured in the ECHO dataset: a lot of values are missing, and many of them seem inconsistent. It should be noted that the log-lin model does not yield significant coefficients for travel duration and its interactions.

The value density parameter is positive and significant. As discussed in Section 2 , this can be interpreted in a number of ways: it may mirror indirectly the additional cost for carriers to transport expensive commodities, or the preference of shippers for speed, imperfectly captured by the travel duration coefficients; it may also be interpreted as evidence of ad valorem pricing and thus of imperfect competition.

The influence on prices of the existence of a production planning is unclear: according to the log-log model, it is significant, and negative. This makes sense: if a shipper can give its carrier(s) visibility on shipments, they can anticipate and therefore be more cost-efficient. However, the variable is not significant anymore in the log-lin model. 
Shipper size variables are also significant: the total number of shipments sent by a shipper per year has a significant negative influence on prices; this may result from transport economies of scale but also from reduced transaction costs. This effect is not observed at all with respect to the shipper-receiver commodity flow. Besides, it is to a certain extent cancelled out by the positive effect of the number of employees of the shipper on prices. Finally, it is not possible to identify an effect of the population of the urban unit on prices.

Regarding transaction costs, three parameters are relevant: the presence of communication by e-mail between shippers and carriers has no visible influence on prices. However, the fact that a shipper and a receiver belong to the same firm, or group, has a significant, positive influence on prices. This is not an intuitive results; one would have thought that this would have helped the coordination of transport, and therefore better prices. The fact that the contrary is observed is not easy to interpret. It may mirror the fact that intra-firm transport is very specific, less prone to mutualization with other clients, or maybe more demanding in terms of level of service, thus causing larger transport costs, and prices.

Thanks to the depth of the ECHO dataset, it was possible to analyze many dimensions of the structure of road freight prices. However, such information is never available in practice. For this reason, a simple model has been developed, where the only explanatory variables are the distance, shipment weight, number of transshipments, and commodity type. This model shows that the parameters of these variables are quite stable, and also that commodity type seems to be able to capture, at least partly, the variables pertaining to the nature of the shipments (value density, conditioning, constraints). It can be considered as a reasonable starting point to introduce these variables in a freight transport simulation model.

\section{Conclusions}

This article does not claim to be the last word on the assessment of the prices' structure in the road freight industry. By using the extensive ECHO survey and multivariate regressions, several conclusions nevertheless emerge in the French case.

First, road freight prices are not a simple linear function of shipments' attributes. As a consequence, we cannot extrapolate shippers and/or carriers characteristics to predict the price charged for a given transport service. This has potentially important implications in the field of freight transport modeling. Second, this price depends on various "technical" attributes that influence the production costs of transport operators, such as load weight, travel duration or distance. But the characteristics of the shipped goods matter too. Expensive shipments and commodities with specific constraints (fragile goods or hazardous materials) tend to be charged at higher prices. Third, the analysis of the prices' structure made it possible to distinguish two specific freight markets. Light shipments are more likely to accom- 
modate multiple transshipments, as opposed to heavy shipments. Since the price paid for former operations is lower, this provides additional rationales for public policies based on investments in logistics platforms. Lastly, we have highlighted the influence of non-traditional factors: A continuous relationship between the transport operators and the shippers decreases the price charged; the bigger the shipper, the fewer he pays; intra-group exchanges tend to be over-priced.

Future research should try to understand more accurately later results, either by analyzing in depth the forces at stake or by finding new variables that describe more precisely the influences of transaction costs and market structures on freight prices. Also, a proper analysis should target the assessment of freight values of the time. Such extension would be of major interest for policy and business analyses.

Acknowledgments This research is part of a study on freight transport modeling realized by the Cerema for the French Ministry of the Environment and Sustainable Development. The authors gratefully thank an anonymous referee for their useful comments.

\section{References}

Baumol, W. J. and Vinod, H. D. (1970) An inventory theoretic model of freight transport demand, Management Science, vol. 16, no. 7, pp. 413-421.

Ben Akiva, M. and de Jong, G. (2013) The Aggregate-Disaggregate-Aggregate (ADA) freight model system, in Freight Transport Modelling, Ben Aliva M., Meersman H., van de Voorde E. (eds). Emerald Group Publishing Ltd.

Cassel, E. and Mendelsohn, R. (1985). The choice of functional forms for hedonic price equations: a comment. Journal of Urban Economics, vol. 18, pp. 135-142.

Combes, F. (2013). On shipment size and freight tariffs: technical constraints and equilibrium prices, Journal of Transport Economics and Policy, vol. 47, no. 2, pp. 229-243.

Combes, F. and Tavasszy, L. (2013). Inventory theory, mode choice and transshipments in freight transport, in Proceedings of the ITEA - Kuhmo Nectar Conference, Evanston, USA.

Demirel, E., van Ommeren, J. and Rietveld, P. ( 2010). A matching problem for the backhaul problem, Transportation Research Part B, vol. 44, pp. 549- 561.

De Jong, D. (2014) Freight Service Valuation and Elasticities, in Modelling Freight Transport, Tavasszy, L. and de Jong, G. (eds), Elsevier, London, UK, Waltham, USA.

Felton, J. R. (1981) Impact of ICC rate regulation upon truck back hauls, Journal of Transport Economics and Policy, vol. 15, no. 3, pp. 253- 267.

Guilbault, M. (2008). Enquête ECHO: Envois-Chargeurs-Opérations de transport: résultats de référence, INRETS.

Guilbault, M., and Gouvernal, E. (2010). Transport and logistics demand: new input from large shippers surveys in France. Transportation Research Record: Journal of the Transportation Research Board, 2168, 71-77, Transportation Research Board of the National Academies, Washington, DC.

Haab, T.C. and McConnel, K.E. (2003). Valuing Environmental and Natural Resources. Edward Elgar.

Halvorsen, R. and Pollakowski, H.O. (1981). Choice of functional form for hedonic price function. Journal of Urban Economics, vol. 10, pp. 37-49.

Kay, M. G. and Warsing, D. P. (2009). Estimating LTL freight rates using publicly available empirical data. International Journal of Logistics: Research and Applications, vol. 12, no. 3 , pp. $165-193$ 
Massiani, J. (2008). Can we use hedonic pricing to estimate freight value of time? EERI Research Paper Series, ${ }^{\circ} 8 / 2008$.

Reme-Harnay, P. (2012) Rapport final: "la formation des prix dans les transports routiers : analyse empirique et analyse économétrique », Report.

Rosen, S. (1974). Hedonic Prices and Implicit Markets: Product Differentiation in Price Competition. Journal of Political Economy, vol. 82, pp. 34-55.

Strandenes, S. P. (2013) Freigh transport pricing models in Freight Transport Modelling, Ben Aliva M., Meersman H., van de Voorde E. (eds). Emerald Group Publishing Ltd.

Szpiro, D. and Hanappe, P. and Gouvernal, E. (1996). Le transport de marchandises, volume, qualité et prix hédoniques. Working Paper, Université de Lille 1.

Tirole, J. (1988). The theory of industrial organization. The MIT Press.

$\mathrm{Xu}, \mathrm{K}$., Windle, R., Grimm, C. and Corsi, T. (1994), Re-evaluating returns to scale in transport, Journal of Transport Economics and Policy vol. 8, no. 3, pp. 275-286.

\section{Appendix}

Table 3 summarizes descriptive statistics of variables used for computations. We present data for both complete and simplified models. We refer to Table 1 for the definition of variables.

\begin{tabular}{l|ccc|ccc|}
$\begin{array}{l}\text { Table 3: descriptive statistics } \\
\text { Models }\end{array}$ & Mean & $\begin{array}{c}\text { Complete } \\
\text { Stand.Dev. }\end{array}$ & Obs. & Mean & $\begin{array}{c}\text { Simplified } \\
\text { Stand.Dev. }\end{array}$ & Obs. \\
\hline Price $(€)$ & 387 & 2,163 & 1,177 & 450 & 2,694 & 4,351 \\
Distance (km) & 347 & 292 & 1,177 & 365 & 292 & 4,351 \\
Weight $(\mathrm{kg})$ & 5,067 & 13,145 & 1,177 & 4,194 & 9,251 & 4,351 \\
1 transport operation & $44 \%$ & - & 1,177 & $42 \%$ & - & 4,351 \\
2 transport operations & $20 \%$ & - & 1,177 & $19 \%$ & - & 4,351 \\
3+ transport operations & $36 \%$ & - & 1,177 & $39 \%$ & - & 4,351 \\
Transport duration (h) & 47 & 260 & 1,177 & 44 & 229 & 2789 \\
Value density (€/kg) & 53 & 166 & 1,177 & 48 & 160 & 3,066 \\
Constraint_hazmat & $3 \%$ & - & 1,177 & $2 \%$ & - & 4,351 \\
Constraint_controlled_T & $7 \%$ & - & 1,177 & $6 \%$ & - & 4,351 \\
Constraint_fragile & $12 \%$ & - & 1,177 & $12 \%$ & - & 4,351 \\
Production_prog & $46 \%$ & - & 1,177 & $45 \%$ & - & 4,351 \\
Total_shipper(t/year) & 19,348 & 61,596 & 1,177 & 25,300 & 133,987 & 4,351 \\
Shipper_workforce & 134 & 260 & 1,177 & 145 & 356 & 4,351 \\
Shipper_receiver_flow & 149 & 440 & 1,177 & 172 & 643 & 3,749 \\
(ship./year) & & & & & & \\
Same_firm & $5 \%$ & - & 1,177 & $6 \%$ & - & 4,351 \\
Same_group & $7 \%$ & - & 1,177 & $7 \%$ & - & 4,351 \\
E_mail_contact & $24 \%$ & - & 1,177 & $24 \%$ & - & 4,351 \\
\hline
\end{tabular}

